\title{
PENGEMBANGAN KAWASAN TERPADU MANDIRI DENGAN PENDEKATAN MODEL ONE VILLAGE ONE PRODUCT (OVOP) DAERAH TRANSMIGRASI RASAU JAYA
}

\author{
Nuraini Asriati \\ UNTAN Pontianak, Indonesia \\ Email: nurainifkip@yahoo.co.id
}

\begin{abstract}
Abstrak: Pengembangan Kawasan Terpadu Mandiri dengan Pendekatan Model One Village One Product (OVOP) Daerah Transmigrasi Rasau Jaya. Penelitian ini bertujuan untuk mengembangkan model Kawasan Terpadu Mandiri dengan pendekatan OVOP. Penelitian ini menggunakan pendekatan kualitatif yang bersifat eksploratif dan evaluatif. Penelitian dilakukan melalui tahap pengembangan dan perancangan, tahap uji coba dalam lingkup terbatas dan tahap validasi berupa eksperimental yang lebih luas. Hasil penelitian menunjukkan bahwa penerapan model OVOP dengan QFD belum seratus persen berhasil karena belum banyak memiliki jaringan nasional maupun Internasional; upaya pengembangan sentra produk OVOP dilakukan berupa: pelatihan, pendampingan tenaga ahli, bantuan sarana usaha, promosi, pameran, pemasaran, fasilitasi permodalan, dan pemberian penghargaan OVOP; pengembangan sentra produk OVOP di Rasau Jaya merupakan kegiatan ekonomi yang sangat mendukung terwujudnya KTM; dan terbentuknya KTM menumbuhkan perilaku pengusaha transmigrasi yang selalu mengembangkan OVOP.
\end{abstract}

Kata Kunci: One Village One Product (OVOP), Kawasan terpadu mandiri (KTM), Daerah Transmigrasi.

\begin{abstract}
Independent Integrated Area Development Using One Village One Product (OVOP) Model in Transmigration Area Rasau Jaya. This research aims to develop a model of independent integrated area with OVOP approach. This study used a qualitative approach that is both exploratory and evaluative. The study was conducted through these three following steps: (1) development and design, (2) limited pilot trial, and (3) experimental validation to broader area. The results showed that the application of OVOP models with QFD was not fully successful. This unsuccessful story was contributed by lacking of a national and international network. A number of efforts was conducted to develop OVOP product, such as: training, expert assistance, assistance for running business, promotion, exhibition, marketing, capital facilitation and OVOP rewards. OVOP product centers development in Rasau Jaya is an economic activity that supports the formation of Integrated Area Independent.
\end{abstract}

Keywords: One Village One Product (OVOP), Integrated Area Independent, Transmigration Area.

\section{PENDAHULUAN}

Pembangunan transmigrasi pada hakikatnya merupakan bagian integral dari pembangunan nasional dan pembangunan daerah, sebagai upaya untuk mempercepat pembangunan terutama di kawasan yang masih terisolir atau tertinggal yang sekaligus dapat meningkatkan kesejahteraan para transmigran dan masyarakat sekitar. Konsep Kawasan Terpadu Mandiri (KTM) diharapkan akan dapat mempercepat perkembangan suatu UPT sampai menjadi lbu Kota 
Kabupaten atau secara umum menjadi pusat pertumbuhan ekonomi dalam waktu $10-15$ tahun. Undang-undang Nomor 15 Tahun1997 tentang Ketransmigrasian dan Peraturan Pemerintah Nomor 2 Tahun 1999 tentang Penyelenggaraan Transmigrasi mengatur bahwa transmigrasi dilaksanakan dengan membangun WPT (Wilayah Pengembangan Transmigrasi) dan LPT (Lokasi Permukiman Transmigrasi).

Berbagai permasalahan yang dihadapi dalam pengembangan unit-unit permukiman transmigrasi di antaranya yaitu tingkat aksesibilitas ke lokasi transmigrasi yang rendah, produksi para transmigran yang tidak dapat dipasarkan, lahan transmigrasi yang marginal (tidak subur), sarana dan prasarana sosial-ekonomi kurang mendukung pengembangan usaha transmigran, serta adanya masalah sengketa kepemilikan lahan. Hal ini menyebabkan kegiatan ekonomi di lokasi transmigrasi tidak berkembang, pendapatan para transmigran tetap rendah, desa transmigrasi tidak memiliki daya tarik bagi para pemilik modal untuk mengembangkan usahanya, dan kebutuhan masyarakat masih tergantung dari luar permukiman. Permasalahan lainnya yaitu penduduk lokal yang berada di sekitar unit-unit permukiman transmigran masih belum mendapat sentuhan pemberdayaan yang setara, sehingga tingkat produktivitas dan pendapatannya masih relatif rendah, serta timbulnya kecemburuan sosial karena adanya perbedaan perlakuan antara transmigran dan masyarakat lokal.

Realitas selama ini menunjukkan bahwa kawasan transmigrasi telah menciptakan pusat-pusat pertumbuhan jauh yang mampu mendorong percepatan pertumbuhan ekonomi wilayah secara significant, hal ini ditunjukkan dengan terbentuknya sejumlah ibukota kabupaten, ibukota kecamatan, dan sentra sentra produksi pertanian yang berasal dari permukiman transmigrasi. Namun disadari bahwa proses pertumbuhan tersebut membutuhkan waktu cukup lama, karena rendahnya produktivitas, kurang lancarnya proses distribusi, dan keterbatasan pasar.

Daerah Rasau Jaya merupakan daerah transmigrasi yang mempunyai potensi lahan dan usaha yang dilakukan masyarakat dan juga merupakan daerah eks transmigrasi yang cukup berhasil. Ibukota Kecamatan Rasau Jaya merupakan pusat perbelanjaan terutama untuk daerah dari sebelah selatan Kecamatan Rasau Jaya. Letaknya sangat strategis menjadi tempat persinggahan untuk beberapa masyarakat di luar Kecamatan Rasau Jaya. Kondisi ini menambah ramainya berbagai aktivitas dan kegiatan masyarakat di Rasau Jaya .

Pertumbuhan penduduk Kecamatan Rasau Jaya mengalami kenaikan dengan tingkat pertumbuhan dari tahun 2008- 2009 mengalami kenaikan sebesar 14,2874\%. Lajunya pertumbuhan penduduk menjadi suatu perhatian pihak terkait karena pengendalian pertumbuhan penduduk berimplikasi pada kesejahteraan masyarakat.

Kecamatan Rasau Jaya sangat strategis dan akses ke ibukota Propinsi Kalimantan Barat terjangkau. Kecamatan Rasau Jaya yang memiliki luas $111,07 \mathrm{Km} 2$. cukup berpotensi untuk dikembangkannya satu desa satu produk (OVOP) namun masih banyak tanah yang belum dapat dimanfaatkan dengan optimal. Potensi ekonomi sudah banyak dilirik oleh 
Tabel 1. Kawasan Terpadu Mandiri Daerah Transmigrasi Rasau Jaya

\begin{tabular}{clcc}
\hline No. & \multicolumn{1}{c}{ Lokasi/Desa } & Luas Desa (ha) & Jumlah KK \\
\hline 1 & Rasau Jaya Umum & 44 & 5206 \\
2 & Pematang Tubuh & 506 & 312 \\
3 & Bintang Mas & 600 & 1202 \\
4 & Rasau Jaya III & 2130 & 3722 \\
5 & Rasau Jaya I & 1392 & 6621 \\
6 & Rasau Jaya II & 1535 & 3743 \\
\hline \multicolumn{5}{c}{ Jumlah } \\
\hline
\end{tabular}

Sumber: Kantor Kecamatan Kubu Raya, 2013

perusahaan besar untuk membangun perkebunan sawit, jagung, nenas, dan ubi kayu.

Salah satu upaya pembangunan perdesaan yang saat ini sedang diperkenalkan di Indonesia adalah pendekatan One Village One Product (OVOP atau Satu Desa Satu Produk). Pendekatan ini merupakan gerakan masyarakat yang mengembangkan potensi yang dimiliki daerah secara terintegrasi untuk meningkatkan pendapatan dan kesejahteraan masyarakat. Pendekatan model One Village One Product ini cocok untuk pengembangan kawasan industri pedesaan. Sentra OVOP merupakan wilayah desa atau kecamatan di mana produk UKM sebagai produk OVOP diproduksi. Model perkembangan kota akan berkembang karena keadaan topografi tertentu atau karena perkembangan sosial ekonomi tertentu. Dasar pemilihan model perkembangan satu desa satu produk (OVOP) akan diterapkan pada Kota Terpadu Mandiri Rasau Jaya adalah untuk mendapatkan model kota yang paling ekonomis.

Konsep Dasar Pembangunan Kota Terpadu Mandiri (KTM) pada hakikatnya suatu Kota yang tidak mungkin terwujud tanpa didukung kegiatan usaha/ekonomi daerahnya, Demikian juga untuk menumbuhkan atau mewujudkan Kota Terpadu Mandiri (KTM) perlu didukung oleh kegiatan usaha transmigran yang berdasarkan keunggulan lokal wilayah.

Oleh karena itu untuk menumbuhkan KTM perlu memberdayakan usaha kecil mikro yang ada di daerah tersebut sehingga mendorong tumbuhnya suatu kota satu produk (OVOP). Wilayah KTM Rasau Jaya meliputi lokasi transmigrasi dan eks lokasi transmigrasi yang memiliki potensi untuk mengembangkan OVOP sebagai berikut:

Berdasarkan tabel 1 di atas, menunjukkan adanya potensi yang dimiliki Rasau Jaya untuk dikembangkan OVOP berdasarkan : 1) letak geografis; 2) Letak administrasi lokasi KTM; 3) Luas lokasi KTM dengan jumlah penduduk 4) Aksesibilitas dan Kondisi Fisik Rasau Jaya; 5) Topografi lokasi KTM dan 6) Penggunaan lahan lokasi KTM Rasau Jaya berdasarkan RTRWP Kalimantan Barat.

Konsep Pengembangan Kota Terpadu Mandiri, diarahkan pada pengembangan komoditas unggulan wilayah melalui system agribisnis dan agro industri dari hulu ke hilir 
bekerjasama dengan investor bidang usaha pertanian. Oleh karena itu untuk menumbuhkan KTM perlu melakukan pembangunan Wilayah Pengembangan Transmigrasi (WPT) yang dapat mendorong tumbuhnya suatu kota/desa (OVOP).

OVOP merupakan pendekatan program pengembangan produk unggulan daerah serta meningkatkan nilai tambah produk dalam rangka meningkatkan kesejahteraan masyarakat. Program One Village One product (OVOP) merupakan kegiatan yang dilaksanakan oleh Kementerian Koperasi dan Usaha Kecil dan Menengah Republik Indonesia yang pelaksanaannya didasari pada Inpres No. 6 Tahun 2007 Tentang Percepatan Sektor Riil dan Pembangunan Usaha Mikro Kecil dan Menengah tanggal 8 Juni 2007 yang mengamanatkan pengembangan sentra melalui pendekatan OVOP. Program ini dilakukan pada produk yang memiliki ciri khas daerah setempat atau produk yang secara kultural masyarakat yang memiliki potensi pasar baik domestik maupun pasar ekspor.

Menurut Wayan (2009) ada kriteria yang harus dimiliki lokasi pengembangan program One Village One Product (OVOP) atau satu desa satu produk, dalam rangka pengembangan Kawasan Industri Mandiri Terpadu yaitu berdaya saing tinggi di pasar domestic dan global. Daerah yang menjadi pengembangan program OVOP harus ada keseragaman jenis usaha, memiliki tata ruang yang jelas, serta memiliki infrastruktur yang bagus.

Berbagai model menjadi input penyusunan konsep model pemberdayaan masyarakat. melalui pemberdayaan pengusaha di daerah transmigrasi diharapkan applicable bagi unit operasional yang terkait di lingkungan dimana peningkatan taraf kesejahteraan masyarakat merupakan tanggung jawab bersama antara Pemerintah Daerah, pusat maupun masyarakat bahkan Perguruan Tinggi sebagai lembaga pengkajian.

Oleh karena itu, peneliti tertarik dan menganggap penting untuk dilakukan penelitian sebagai starting point untuk memberikan kontribusi kepada pemerintah daerah dan solusi kebijakan dengan pengembangan model One Village One Product unggulan dalam membangun Kawasan Industri Terpadu Mandiri Daerah Transmigrasi Kabupaten Kubu Raya Kalimantan Barat.

\section{Pengembangan Kawasan Terpadu Mandiri}

Kota Terpadu Mandiri (KTM) adalah kawasan yang direncanakan untuk menciptakan kawasan yang cepat tumbuh di kawasan lokasi eks transmigrasi. Pekerjaan masyarakat di kawasan ini bekerja pada sektor pertanian. Laju pertumbuhan perekonomian di kawasan ini dipacu dengan beberapa sektor, di antaranya sektor jasa, sektor listrik, gas, air bersih, bangunan, keuangan dan komunikasi.

Membangun kawasan industri terpadu harus mendapat dukungan penuh dari semua stakeholder terutama Pemerintah Kabupaten sebagai regulator dalam hal ini memiliki peranan yang sangat sentral. Tata kelola yang baik akan menentukan keberhasilan kawasan industri terpadu. Dengan tata kelola yang baik, transparan dan akuntabel, pendirian kawasan industri terpadu akan memberikan manfaat yang optimal bagi semua pihak yang terlibat 
terutama pelaku industri, masyarakat sekitar kawasan dan pemerintah kabupaten. Sebaliknya tata kelola yang buruk akan menyebabkan investor enggan untuk melakukan investasi.

Pembangunan wilayah melalui alternatif transmigrasi harus dilaksanakan secara bersama oleh lintas sektor dan lintas pemerintahan. Membangun kawasan industri akan menghasilkan dampak sosial bagi masyarakat dan dampak lingkungan sehingga risiko konflik sosial, perubahan tatanan sosial sebagai akibat dari pendirian kawasan industri bisa dikelola dengan baik. Sebuah preliminary study yang menyeluruh dan mendalam tentang dampak sosial, lingkungan hidup akibat pendirian kawasan industri pada masyarakat sekitar harus dilakukan sehingga pendirian kawasan industri ini memberikan manfaat bagi masyarakat, menjaga kelestarian lingkungan hidup.

Kawasan KTM Rasau Jaya seluas 97.710 $\mathrm{Ha}$, berpenduduk 57.204 jiwa, adalah kawasan Transmigrasi yang pertumbuhannya dirancang menjadi pusat pertumbuhan melalui pengelolaan sumberdaya alam berkelanjutan .Luas KTM yang mencapai $97.710 \mathrm{Ha}$ dan terletak pada lokasi strategis mempunyai banyak peluang usaha, hal ini dapat disampaikan karena PDRB Kabupaten yang cukup tinggi yang berasal dari lapangan usaha unggulan yakni pertanian, industri pengolahan, perdagangan. PDRB kabupaten berdasarkan BPS Kabupaten tahun 2004 sebesar Rp5.150.285.590.000,-

Produksi unggulan di KTM ini adalah padi, ubi dan jagung maka peluang untuk membangun One village one product sangat potensial, sesuai prinsip prnsip OVOP. Kawasan Industri Terpadu Mandiri merupakan sebuah kawasan terpadu yang dikelola secara terintegrasi yang menyediakan berbagai macam fasilitas keperluan industri mulai penyediaan gudang, air bersih, listrik, tempat produksi pengelolaan limbah terpadu, infrastruktur seperti jalan atau pelabuhan.

Adapun yang menjadi komponen dalam kawasan terpadu mandiri terdiri dari komponen: a) pemukiman penduduk yang sudah ada; b)Permukiman transmigrasi yang sudah diserahkan pembinaannya; c) Lokasilokasi transmigrasi yang masih dibina, dan d) Areal yang dapat direncanakan untuk permukiman transmigrasi yang baru.

\section{Pendekatan OVOP}

Pendekatan pembangunan kawasan terpadu mandiri terdiri dari pendekatan eksogenus dan pendekatan endogenus. Pembangunan yang didasarkan pada pendekatan eksogenus atau modernisasi industri adalah dengan mengintroduksi investasi atau sumber daya dari luar, membutuhkan prasyarat jaminan buruh berkualitas tinggi, kecukupan industri klaster, pengembangan infrastruktur (khususnya sarana transportasi) dan daya tarik kebijakan industri yang bermanfaat.

Sedangkan pembangunan dengan pendekatan endogenus yaitu pembangunan dengan memanfaatkan potensi sumberdaya dan modal secara penuh, serta memperhatikan keseimbangan lingkungan. "Pendekatan model One Village One Product ini cocok untuk pengembangan kawasan industri pedesaan.

OVOP adalah suatu gerakan masyarakat yang secara integratif berupaya 
meningkatkan kesadaran masyarakat terhadap potensi dan kekayaan daerah, meningkatkan pendapatan para pelaku usaha dan masyarakat sekaligus meningkatkan rasa percaya diri dan kebanggaan terhadap kemampuan yang dimiliki masyarakat dan daerahnya. Sumber daya alam ataupun produk budaya lokal serta produk khas lokal yang telah dilakukan turun temurun dapat digali dan dikembangkan untuk menghasilkan produk bernilai tambah tinggi sesuai tuntutan dan permintaan pasar.

I Wayan mengemukakan bahwa ada tiga prinsip dalam pengembangan OVOP itu adalah Pertama, lokal tapi Global, di mana gerakan OVOP ditujukan untuk mengembangkan dan memasarkan produk unggulan yang mampu mendunia dan jadi kebanggaan rakyat setempat. Kedua, kemandirian dan kreativitas dengan menggunakan potensi lokal atau regional di wilayah masing-masing. Ketiga, Pengembangan sumber daya manusia sebagai komponen terpenting untuk menjamin pelaksanaan prinsip tersebut. Sedangkan menurut Fauzi untuk mendalami pengembangan OVOP, implementasi konsep itu memerlukan kepemimpinan di daerah yang kuat yang mampu menggerakkan masyarakat berproduksi suatu produk yang memiliki daya saing tinggi. Pengembangan OVOP merupakan solusi terbaik untuk memberdayakan dan membangun masyarakat di daerah sesuai dengan kemampuan daerah tersebut. OVOP salah satu langkah menuju pengelompokan industri di sektor UKM yang bertujuan mengangkat produk unggulan daerah agar dapat berkembang dan masuk ke pasar lebih luas. Dengan fokus pada satu produk unggulan daerah dan padat karya, OVOP juga akan menyerap banyak tenaga kerja lokal. Di Indonesia terdapat sekitar 74 ribu desa yang memiliki keunikan atau ciri khas. Namun, sekitar $65 \%$ penduduknya masih tergolong miskin dan berpendapatan rendah. Mayoritas desa tersebut eksis di sektor pertanian. Dengan kultur tersebut, sangatlah potensial OVOP dikembangkan di desa di daerah transmigrasi. Oleh karena itu, untuk menggairahkan ekonomi kerakyatan, diperlukan peluang pengembangan UKM berbasis sumber daya lokal. Dengan kemandirian yang menjadi landasan pengembangan OVOP, konsep ini sesungguhnya tidak akan membebani pemerintah daerah. Justru akan mengurangi beban pemerintah daerah dalam penyelesaian masalah pengangguran dan kesejahteraan rakyat.

Keberadaan produk unggulan bisa dijadikan sebagai salah satu kebanggaan pemerintah daerah yang nantinya diharapkan akan terjadi trickle down effect dari inkubator bisnis yang berimbas pada kemajuan UKM di setiap daerah, bahkan bisa meningkatkan pendapatan nasional negara. Dalam upaya mendukung pengembangan OVOP, diperlukan sinergi berkelanjutan di antara para stakeholder dengan pelaku usaha. Pemerintah daerah dengan instansi terkait, seperti Kementerian Riset dan Teknologi, Kementerian Koperasi dan UKM, Kementerian Perindustrian, serta Kemenko Perekonomian, perlu bekerja sama dalam rangka pengembangan OVOP di suatu daerah. Terutama terkait riset dan teknologi produk, desain, hak paten atas produk, 
pendistribusian teknologi, serta dalam hal menopang aspek promosi produk.

Salah satu aspek yang harus benar-benar dipersiapkan ialah teknis pendampingan. Tiap daerah mustahil bisa sukses melakukan program OVOP dengan sekadar mencontoh daerah lain yang menjadi proyek pencontohan tanpa pendampingan, pelaksanaan OVOP hampir pasti sulit berhasil. Sebab, tiap daerah memiliki masalah fundamental seperti keterbatasan teknologi serta penetrasi pasar yang rendah.

Keberhasilan OVOP, selain dapat menjadi pilihan untuk membantu pencapaian swasembada dan ketahanan pangan, juga untuk meningkatkan daya saing dan keunggulan produk Indonesia. Produk lokal yang dihasilkan akan diberi sentuhan tren warna, tekstur, dan material agar tampil modern tanpa cita rasa lokal. Para perajin diajak untuk memahami trend dengan mentransformasi desain produk dengan mengombinasikan sentuhan tren baru ini. Dengan demikian, produk-produk yang dihasilkan dapat mampu bersaing di tengah pasar global. Pasar modern saat ini memang tengah dijangkiti virus yang berlabel kontemporer. Maka itu, para produsen di daerah harus mampu memahami apa yang diminta oleh pasar global saat ini (Media Indonesia, 15 September 2011/ humasristek).

Sentra OVOP merupakan wilayah desa atau kecamatan di mana produk UKM sebagai produk OVOP diproduksi. Homogenitas produk, lokasi, akses jalan, sumber bahan baku, sumberdaya manusia, serta komitmen pemerintah daerah merupakan pertimbangan utama dalam penentuan wilayah/sentra OVOP. Untuk menentukan sentra OVOP terdapat beberapa criteria antara lain: a) Wilayah yang mempunyai potensi sumberdaya unggulan yang dikembangkan menjadi barang/produk bernilai tambah tinggi berorientasi ekspor; b) Wilayah yang masyarakatnya telah melakukan kegiatan produksi barang/produk yang sama/sejenis ; c) Produk yang diproduksi memiliki keunikan dan kearifan lokal; d) Adanya komitmen dan fasilitasi Pemerintah Daerah terhadap pengembangan produk e)Memiliki pengurus sentra yang dapat berupa kelompok usaha, KUB, koperasi, paguyuban, asosiasi. f) Ketersediaan bahan baku di daerah setempat.

Ada beberapa syarat yang harus dipenuhi sebagai produk OVOP yaitu: 1) Batasan Produk (Memiliki keunikan/kearifan lokal, kualitas ekspor, diproduksi secara kontinu.; 2) Produsen (memiliki legalitas usaha); 3) Jenis Produk IKM. Unsur-unsur yang dinilai pada ketiga aspek di atas mencakup: Sumber bahan baku, Pengembangan produk/inovasi, Keunikan lokal, Sejarah produk, Kemasan ,Standar yang dimiliki, Teknologi yang digunakan, Kapasitas produksi, Perijinan, Manajemen usaha, Pembukuan, Pemasaran, peningkatan omzet penjualan, Dampak lingkungan. Keterlibatan tenaga kerja dan masyarakat sekitar. Keuntungan yang disumbangkan kepada masyarakat dan lingkungannya (Kementerian Perindustrian, 2012: 20-22).

\section{METODE}

Penelitian ini berupa Implementasi model One Village One Product dalam pengembangan daerah Kawasan Terpadu Mandiri Rasau Jaya. Teknik pengumpulan 
data melalui observasi langsung, penyebaran angket dan wawancara mendalam (Bogdan dan Taylor, 1993:27). Pendekatan penelitian digunakan Development Research (Borg \& Gall, 1989:781-802) yang diawali dengan pengembangan model One Village One Product dan dilanjutkan dengan tahapan implementasi membangun kawasan industri terpadu mandiri pada daerah transmigrasi. Penelitian ini dilakukan dengan pendekatan kualitatif yang bersifat eksploratif dan evaluatif. Penelitian eksploratif dilakukan b e $r$ tujuan untuk pemetaan 50 orang pengrajin /pengusaha yang siap dengan program OVOP di Kawasan Terpadu Mandiri Rasau Jaya. Penelitian evaluatif dilakukan untuk mengetahui hasil pelaksanaan OVOP yang telah dilakukan 50 orang perajin/pengusaha di Kawasan Terpadu Mandiri Rasau Jaya melalui tiga tahap yaitu tahap pengembangan dan perancangan, tahap uji coba dalam lingkup terbatas dan tahap validasi berupa eksperimental yang lebih luas.

\section{HASIL DAN PEMBAHASAN}

Kawasan KTM Rasau Jaya terdiri dari empat kecamatan salah satunya adalah Kecamatan Rasau Jaya yang meliputi enam desa antara lain Rasau Jaya umum, Bintang Mas, Rasau Jaya I, rasau Jaya II, rasau Jaya III dan Pematang Tujuh. Secara geografis terletak pada Kawasan Rasau Jaya ini terletak pacta 109. 14 30,83"-190 26 30,65" Bujur Timur dan 00.11 30,39" - 00.19 39,42" Lintang Selatan Kawasan perencanaan yang akan dijadikan kawasan industri terpadu mandiri Rasau Jaya sekitar 97.710 ha atau $11,83 \%$ dari Keseluruhan wilayah yang ada di daerah Kabupaten Pontinak. Kawasan ini sangat strategis dalam bidang kegiatan bisnis karena aksesibilitas cukup baik, di mana produksi unggulan adalah padi dengan luas panen $2.709 \mathrm{Ha}$, dan rata-rata produksi per hektar 23,06 Kw/Ha. Selain itu adalah jagung dan ubi kayu, luas panen jagung mencapai 246,52 Ha dengan rata-rata produksi per hektar 18,29 $\mathrm{Kw} / \mathrm{ha}$, sedangkan ubi kayu seluas $991 \mathrm{Ha}$ dengan rata-rata produksi mencapai 127,25 $\mathrm{Kw} / \mathrm{ha}$. Sebagian besar Kawaan KTM Rasau Jaya mempunyai kondisi topografi yang relatif datar dengan kemiringan lahan rata rata antara 0-3\%.. Hal ini dapat dilihat pada Gambar 1.

Dikaitkan dengan prinsip-prinsip mendasar OVOP, program OVOP yang dilaksanakan oleh pemerintah memiliki perbedaan yang cukup mendasar. Prinsip pertama yaitu Local but Global yang bermakna menghasilkan produk atau jasa yang bernilai lokal dan dapat diterima secara global dalam prinsip OVOP, dilaksanakan dengan cara meningkatkan kualitas produk melalui proses pelatihan teknis, pen damping an, peningkatan mutu produksi dan desain Hasil akhir pelatihan yang dilakukan oleh HW Trans Rasau Jaya tidak mengindikasikan adanya peningkatan dalam produksi produk yang dapat diterima secara global sehingga perlu pendampingan selama 6 bulan oleh HW Trans mulai dari standar produk sampai dengan akses pemasaran.

Prinsip dasar kedua OVOP yaitu Self reliance and creativity yang bermakna memanfaatkan potensi yang dimiliki secara kreatif dengan usaha-usaha yang mandiri sudah cukup terlihat dalam pelaksanaan OVOP di Rasau Jaya. Dengan memanfaatkan 


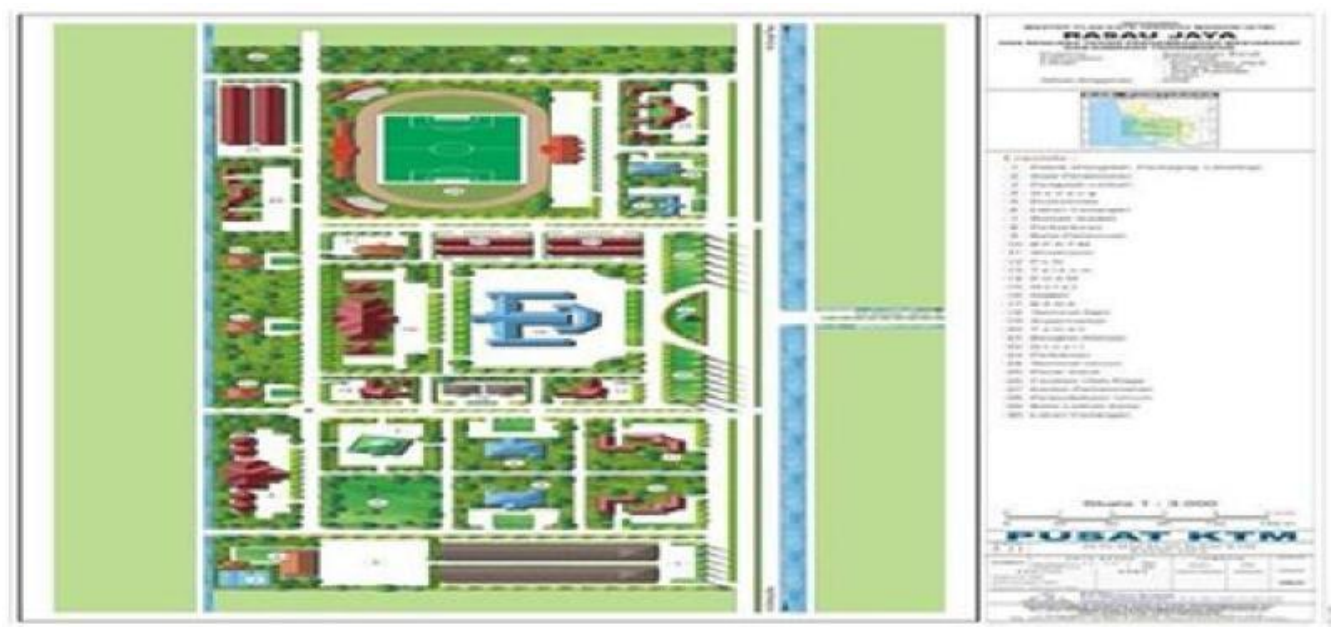

Gambar 1. Kawasan Industri Terpadu Mandiri Rasau Jaya

potensi sumber daya alam sebagai unggulanya produk yang terbuat dari bahan baku beras, dan jagung, sedangkan sumber daya manusia yang telah lama dimanfaatkan oleh masyarakat Rasau Jaya dalam kehidupan sehari-hari, melalui program OVOP mendapatkan dukungan yang lebih besar dari pemerintah seperti adanya pendampingan oleh HW Trans.

Prinsip ketiga yaitu Human resource development memiliki makna mengembangkan potensi masyarakat agar memiliki semangat untuk kreatif dan mampu menghadapi tantangan. OVOP sebagai program pemerintah tidak difokuskan pada pengembangan potensi masyarakat daerah secara menyeluruh sehingga semangat OVOP seolah-olah hanya diperkenalkan pada peserta program yaitu perajin dan pengusaha mikro saja.

Pada dasarnya pelaksanaan OVOP di Kawasan Terpadu Mandiri Rasau Jaya belum sesuai dengan prinsip mendasar OVOP yang seharusnya selalu ada dalam penerapan OVOP. Ketidaksesuaian ini disebabkan oleh belum adanya kesadaran masyarakat dalam langkah pelaksanaan program OVOP yang disusun pemerintah karena bersifat topdown.

Dengan menjadinya Kecamatan Rasau Jaya sebagai Kota Terpadu Mandiri (KTM) mengakibatkan bertambahnya jumlah penduduk dari transmigran yang datang ke Rasau Jaya. Bertambahnya jumlah penduduk mengakibatkan meningkatnya aktivitas ekonomi dan dibarengi oleh bertambahnya kebutuhan lahan yang mewadahi aktivitas pembangunan tersebut. Ketersediaan lahan ditentukan berdasarkan produksi aktual setempat dari semua komoditas OVOP yang ada di wilayah tersebut. Berikut sebaran potensi yang dimiliki kawasan KTM Rasau Jaya baik demografi dan sosial masyarakat pada Tabel 2.

Berdasarkan Tabel 2, menunjukkan bahwa kegiatan perdagangan di Kawasan Terpadu mandiri Rasau Jaya tidak terlepas dari kegiatan perdagangan yang ada di pusat kota Pontianak. Pengembangan agribisnis dilakukan dengan membangun jaringan kerja yang dilaksanakan dengan mengembangkan pola kerjasama dan kemitraan dari berbagai komponen dari berbagai komponen dan kekuatan swadaya masyarakat, dunia usaha, 
Tabel 2. Potensi Yang Dimiliki KTM Rasau Jaya

\begin{tabular}{clc}
\hline No & \multicolumn{1}{c}{ Komponen } & Keterangan \\
\hline 1 & Luas Wilayah & $111.07 \mathrm{Km}$ \\
2 & Desa & 6 desa \\
3 & Jumlah Penduduk & 23.499 \\
4 & Laju Pertumbuhan Penduduk & 2,35 \\
5 & Kegiatan Masyarakat per Km & 212 \\
6 & Kegiatan Masyarakat per desa & 3.917 \\
\hline
\end{tabular}

dan unsur perguruan tinggi yang memiliki komponen dan kosistensi serta kepedulian untuk membangun secara berkesinambungan.

Pengrajin dan pengusaha dibangun kesadaran akan pentingnya terus berkreasi dalam mengembangkan potensi produk, baik secara desain, maupun secara teknik produksi dan tidak terus menerus tergantung pada desain yang diberikan pembeli. Pengrajin dan pengusaha harus memahami dengan pasti pasar luar negeri yang akan dituju, sehingga berbagai pengetahuan mengenai desain, selera dan trend akan target pasar menjadi sangat penting. Pengembangan desain berdasarkan permintaan perantara (buyer) harus dibatasi. Desainer memiliki peran yang sangat signifikan dalam mengembangkan desain yang dapat mempertahankan nilai-nilai tradisional. Program pendampingan dititikberatkan pada pengembangan desain tidak terbatas pada proses pelatihan teknis saja, tetapi juga pendampingan oleh desainer professional yang berfungsi sebagai 'bank' desain dan konsultan.

Pelaksanaan rangkaian program OVOP lebih efektif dalam setiap tahun, termasuk tahap monitoring dan evaluasi. Pelaksanaan evaluatif menunjukkan bahwa 1) memanfaatkan semua prinsip OVOP bukan hanya sebagai sebuah pendekatan untuk memajukan potensi UKM tetapi juga sebagai sebuah upaya untuk membangun suatu daerah.; 2) Melibatkan masyarakat daerah secara meluas dalam melakukan identifikasi permasalahan yang dihadapi oleh U KM dan masyarakat agar seluruh masyarakat merasa memiliki dan terlibat dalam pelaksanaan program OVOP.

Pendekatan OVOP harus mampu memunculkan motivasi masyarakat untuk mandiri, dengan cara membuat pengklasifikasian yang lebih spesifik mengenai perajin atau pengusaha yang akan diikutsertakan dalam program OVOP agar perajin atau pengusaha yang memenuhi persyaratan saja yang akan diikutsertakan program OVOP.

Salah satu andalan KTM Rasau Jaya adalah industri rumah tangga yang mampu mengolah beragam komoditas pertanian menjadi produk pangan dengan pasar yang mampu menembus luar daerah. Produk olahan pangan itu di antaranya marning, rengginang, maupun kerupuk ubi. Namun, walau masih terdapat sejumlah kendala untuk mengembangkan produk olahan pangan tersebut. Misalnya modal, teknologi 
Tabel 3.Pemetaan Produk OVOP Berdasarkan Lokasi KTM Rasau Jaya

\begin{tabular}{|c|c|c|c|c|c|c|c|c|}
\hline \multirow[b]{2}{*}{ No } & \multirow[b]{2}{*}{$\begin{array}{l}\text { Jenis } \\
\text { Usaha }\end{array}$} & \multirow[b]{2}{*}{$\begin{array}{l}\text { Rasau } \\
\text { Jaya I }\end{array}$} & \multirow[b]{2}{*}{$\begin{array}{l}\text { Rasau } \\
\text { Jaya II }\end{array}$} & \multicolumn{2}{|c|}{ Nama Desa } & \multirow[b]{2}{*}{$\begin{array}{r}\text { Pematan } \\
\text { g Tujuh }\end{array}$} & \multirow[b]{2}{*}{$\begin{array}{c}\text { Bintang } \\
\text { Mas }\end{array}$} & \multirow[b]{2}{*}{ Jlh } \\
\hline & & & & $\begin{array}{l}\text { Rasau } \\
\text { Jaya III }\end{array}$ & $\begin{array}{l}\text { Rasau } \\
\text { Jaya } \\
\text { Umum }\end{array}$ & & & \\
\hline 1 & Rengginang & 3 & 3 & 2 & 2 & 1 & 1 & 12 \\
\hline 2 & Marning & 1 & - & - & 1 & - & - & 2 \\
\hline 3 & Kerupuk & 6 & 3 & 2 & 3 & 1 & 1 & 16 \\
\hline 4 & Keripik & 3 & 1 & 1 & 1 & 1 & - & 7 \\
\hline 5 & Torratello & - & - & - & 2 & - & - & 2 \\
\hline 6 & Kue & - & - & - & 1 & - & 1 & 2 \\
\hline 7 & Dodol & - & - & - & 1 & 1 & - & 2 \\
\hline 8 & Minuman & - & - & - & 2 & - & - & 2 \\
\hline 9 & Kerajinan & - & - & 1 & 1 & 2 & 1 & 5 \\
\hline & Jumlah & 13 & 7 & 6 & 14 & 6 & 4 & 50 \\
\hline
\end{tabular}

Sumber: Ketua HW-Trans, 2013

kemasan, hingga jangkauan pasar yang lebih luas.

Kawasan transmigrasi Rasau Jaya tidak terlepas dari kegiatan budidaya pertanian yang menghasilkan beragam bahan pangan, termasuk untuk industri rumah tangga sebagai nilai tambah dari hasil kegiatan usaha tani yang dilakukan masyarakat. Salah satu persoalan utama, ketika ada yang tertarik terhadap produk yang dihasilkan dan perlu dalam jumlah banyak, industri rumah tangga tak jarang kesulitan untuk memenuhinya karena kapasitas industri yang masih kecil dengan sumber daya dan sumber dana yang terbatas serta alih teknologi untuk peningkatan kualitas kemasan dan produk. Setiap pengusaha produk OVOP selalu meningkatkan jenis produknya, kemasan dan labelnya dan saling bersinergi antara pengusaha satu dengan lainnya sehingga setiap desa memiliki potensi yang sama dalam satu kecamatan. Hal ini dapat pada Tabel 3.
Kota Terpadu Mandiri (KTM) Rasau Jaya menjadi pusat pertumbuhan yang mampu mengelola sumber daya alam secara berkelanjutan. Industri rumah tangga (home industry) menjadi salah satu andalan daerah eks transmigrasi itu. Keberadaan KTM Rasau Jaya sebagian besar dari kegiatan usaha tani, sehingga teknologi pengolahan hasil pertanian memberi nilai tambah dalam meningkatkan kesejahteraan masyarakat. Industri rumah tangga tersebut mampu mengolah beragam komoditas pertanian menjadi produk industri olahan pangan dengan pasar yang sudah mampu menembus luar daerah. Produk olahan pangan itu di antaranya marning, rengginang, berbagai macam rasa kerupuk, torratello, keripik, kerajian, aneka kue basah dan kering, batako dan gerabah keramik. Berdasarkan sebaran angket kepada pengusaha/perajin di Kawasan Terpadu Mandiri Rasau Jaya berkaitan dengan pendekatan OVOP diperoleh ada beberapa kriteria penilaian yang digunakan dalam aspek produksi 


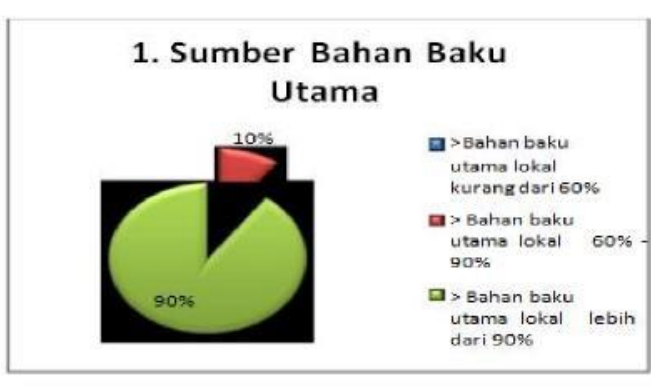

3. Nilai tambah Produksi

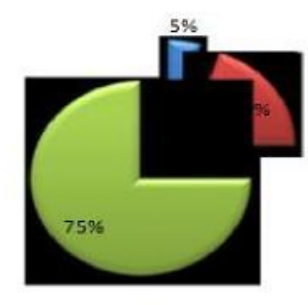

D) Nilai tambah

$$
\text { dari } 20 \%
$$

a $>$ Nilai tambah produksi $20 \%-60 \%$

Q > Nilai tambah produksi lebih dari $60 \%$

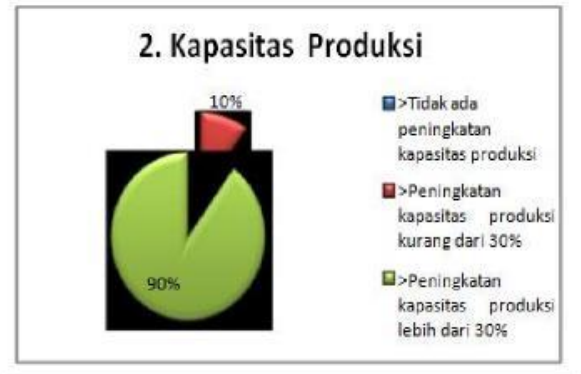

4. Lingkungan

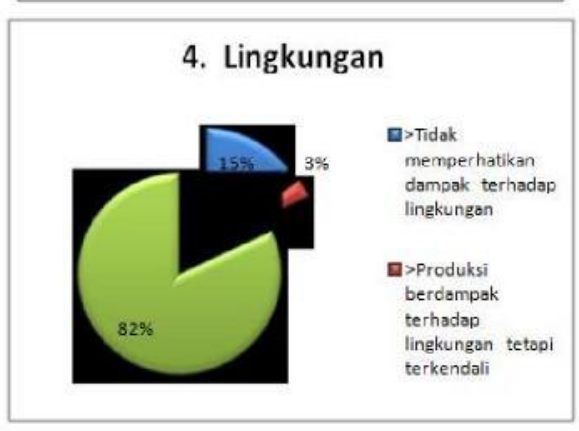

Gambar 2. Sumber Utama

seperti sumber utama bahan baku, kapasitas produksi, nilai tambah produksi, dan lingkungan secara berturut turut dapat dilihat pada Gambar 2.

Berdasarkan Gambar 2 menunjukkan bahwa 90\% sumber utama lokal yang menjadi ciri khas Rasau Jaya yaitu ubi dan jagung. Peningkatan kapasitas produksi di atas $30 \%$ per tahun sebanyak $90 \%$ pengusaha Rasau Jaya. Produk yang diolah dari sumber utama Rasau jaya memiliki nilai tambah produksi di atas $60 \%$ walau tidak berbasis ekspor sebanyak $75 \%$. Sebagian besar dalam memproduksi pengusaha memperhatikan dampak lingkungan.
Selain itu kriteria OVOP menilai konsistensi kualitas dan kuantitas produk, pengembangan produk, merek seperti dideskripsikan pada Gambar 3. Konsistensi kualitas dan kuantitas produk setiap produksi pada jumlah yang sama baik ada pesanan maupun tidak pesanan. Pengembangan produk selalu dilakukan oleh pengusaha/perajin berdasarkan hasil kreativitas dan inovasi produk sebanyak 30\% dan selebihnya masih produk asli yang diversifikasi rasa dan bentuk. Penggunaan merek produk sudah mendapat PRT dan didaftar namun belum memiliki HKI sebanyak $60 \%$.
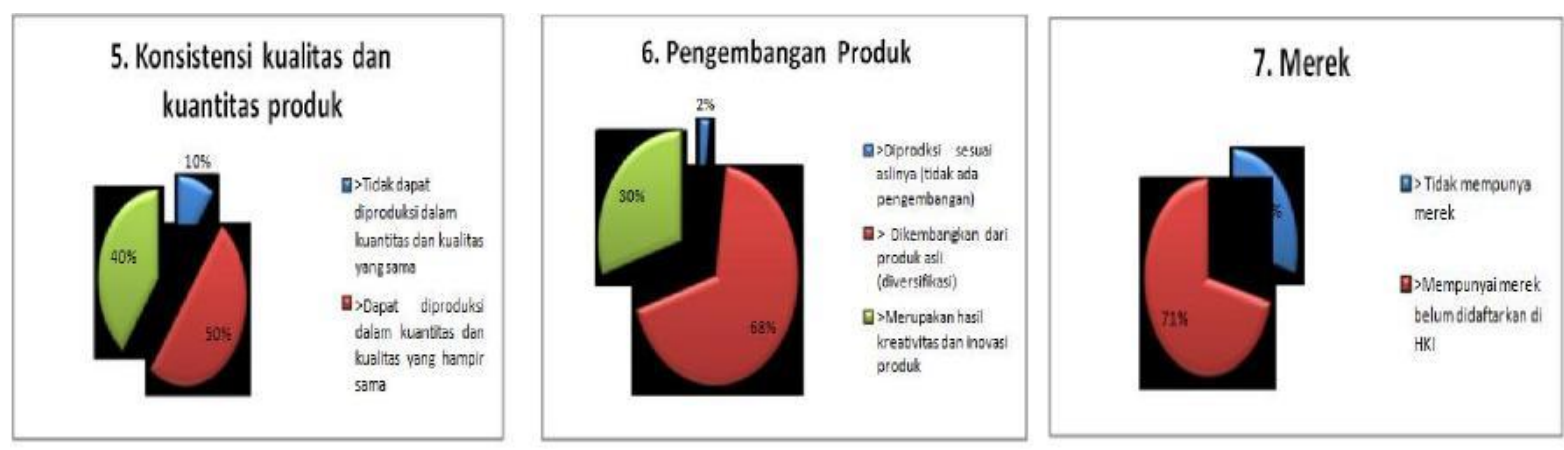

Gambar 3. Kualitas dan kuantitas produk, pengembangan produk, dan merek 

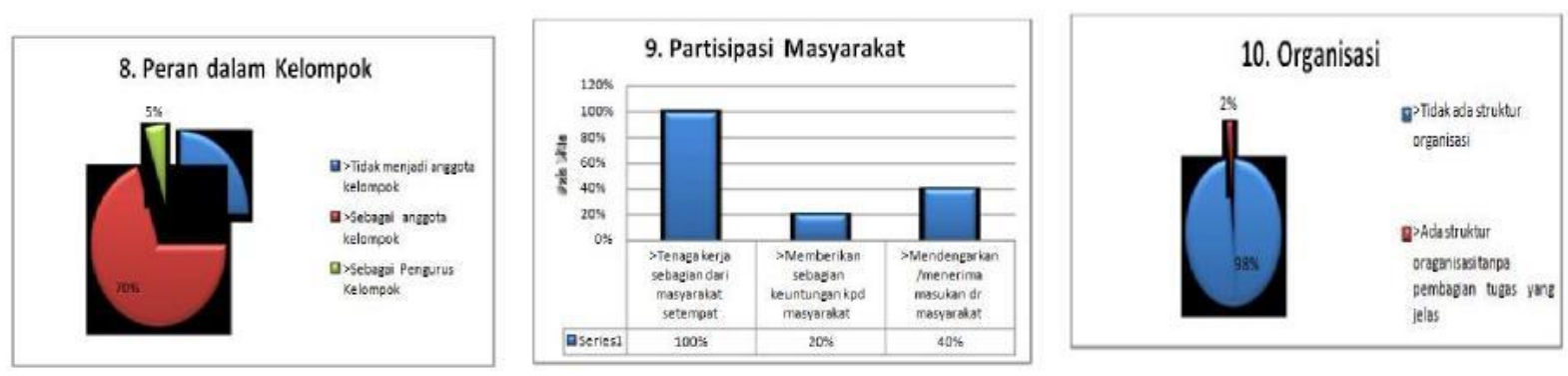

Gambar 4. Peran pengusaha dalam kelompok

Peran pengusaha dalam kelompok dan partisipasi serta organisasi /manajemen secara rinci dapat di lihat pada Gambar 4. Sebagian besar (70\%) pengusaha menjadi anggota kelompok HW Trans KTM Rasau Jaya sedangkan $25 \%$ tidak tergabung dalam Himpunan Wirausaha Kawasan Terpadu Mandiri. Hal ini disebabkan keterbatasan waktu untuk mengikuti kegiatan yang dilakukan HW Trans. Namun untuk mengembangkannya lebih lanjut, masih terdapat sejumlah kendala, di antaranya permodalan, teknologi pengeringan kerupuk maupun keripik jika musim hujan, kemasan, dan jangkauan pasar luar negeri yang menjadi ciri khas OVOP. Berdasarkan wawancara kepada sebagian pengusaha terdapat sejumlah kendala dalam mengembangkan kegiatan industri rumah tangga dan membutuhkan penanganan komprehensif sehingga usaha pengembangan bisa sejalan dengan hasil yang akan diperoleh masyarakat. Rasau Jaya merupakan salah satu kawasan transmigrasi yang berhasil berkat dukungan dari pemerintah dan kemauan masyarakatnya untuk maju dan berkembang. Motivasi yang mereka miliki diharapkan bisa menular kepada kawasan transmigrasi lainnya, terutama kawasan baru sehingga bisa maju dan berkembang, serta mampu meningkatkan taraf kehidupan masyarakat.
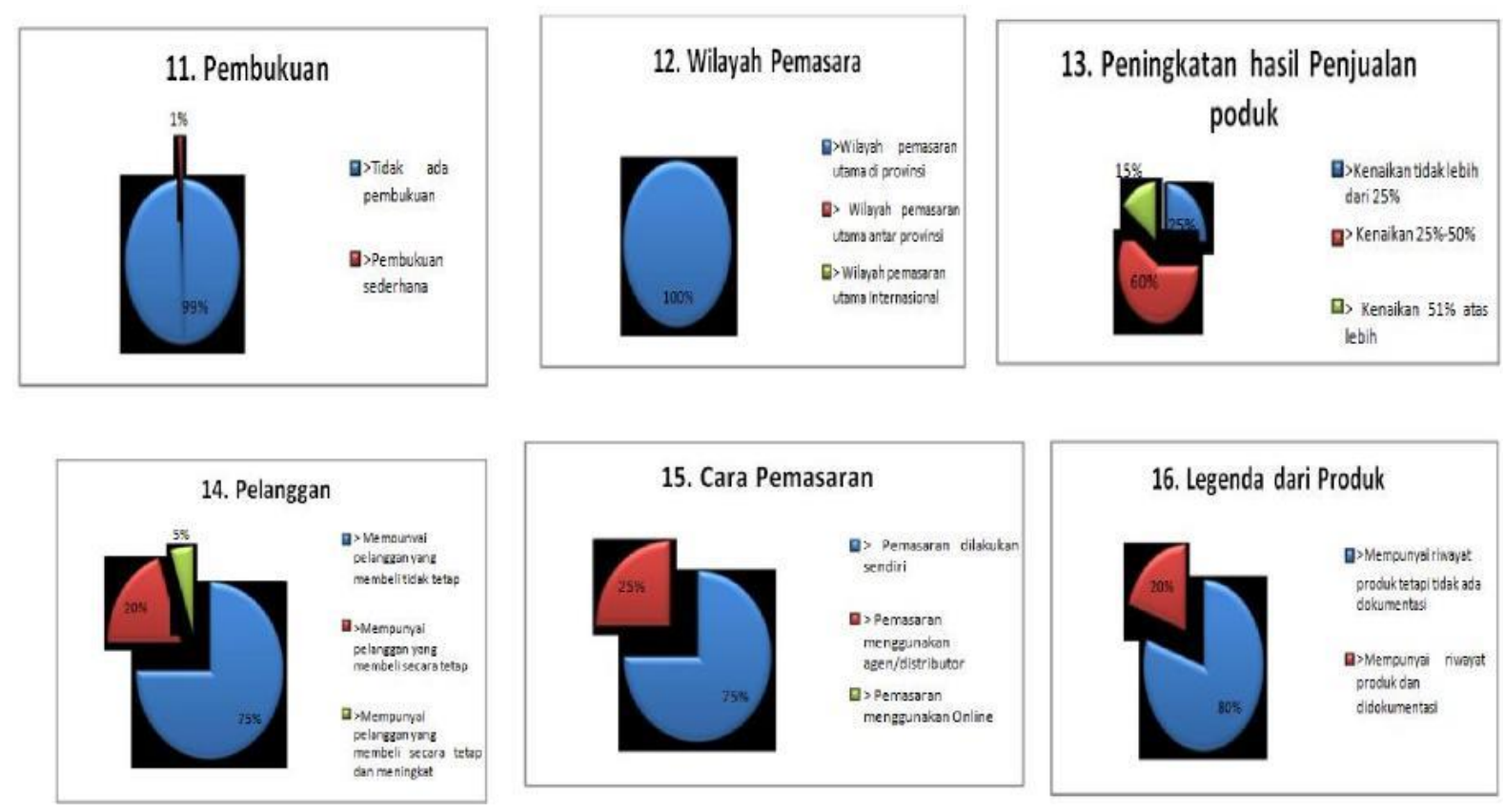

Gambar 5. Manajemen Usaha 

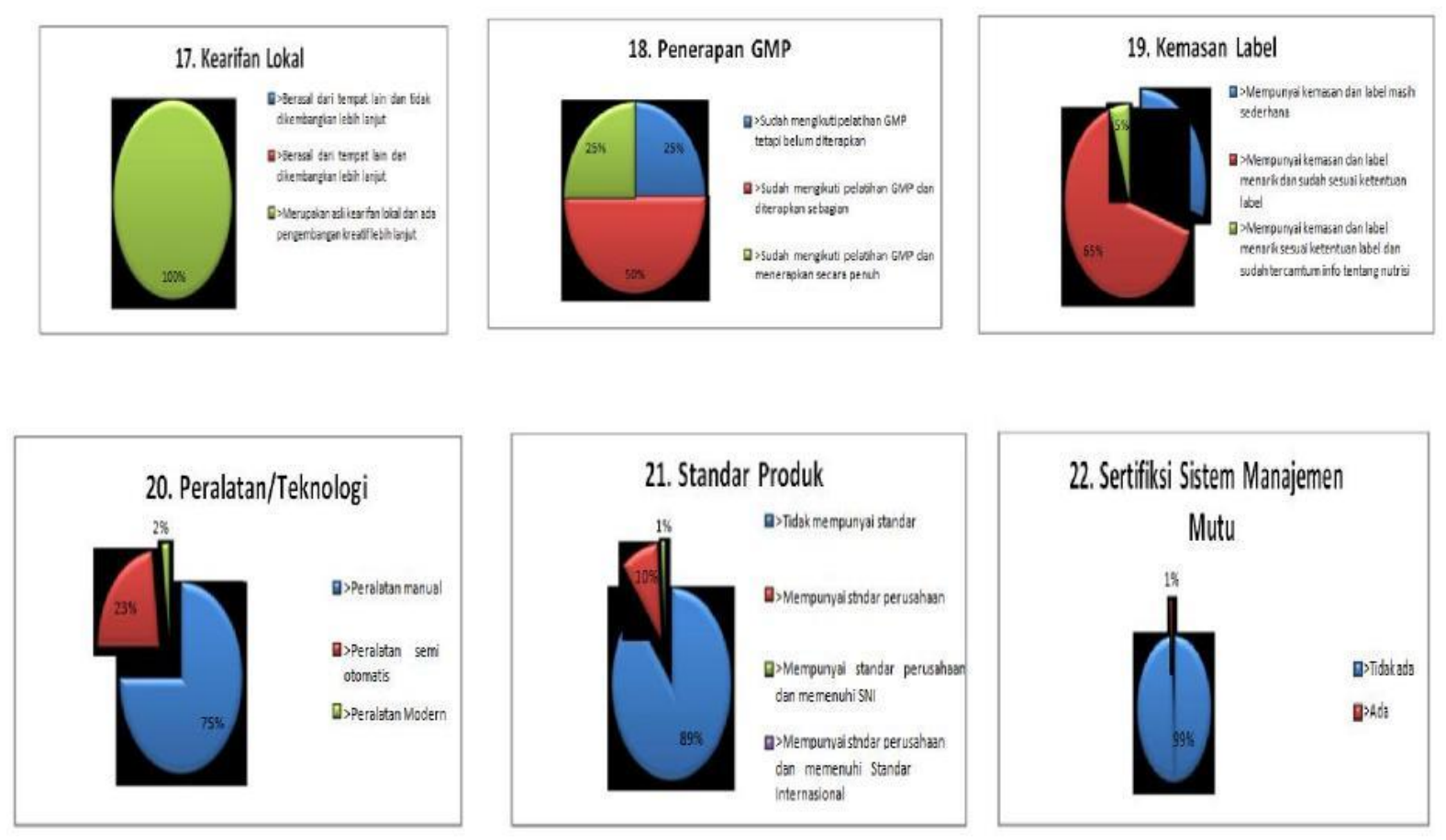

Gambar 6. Perilaku Usaha
Tenaga kerja 100\% diperoleh dari daerah Kawasan Terpadu Mandiri Rasau Jaya sehingga memberikan keuntungan kepada masyarakat setempat walau masih kecil kontribusinya. Manajemennya masih belum memiliki struktur organisasi sebanyak $98 \%$ sedangkan $2 \%$ memiliki struktur tetapi belum adanya job description pada setiap tenaga kerja. Begitu juga pembukuannya belum dilakukan pembukuan terpisah antara keuangan usaha dengan keuangan rumah tangga, hanya $1 \%$ yang sudah membuat pembukuannya. Wilayah pemasaran produk hanya di wilayah propinsi belum mengglobal. Kenaikan produksi hanya sebatas $25 \%-50 \%$ untuk memenuhi langganan menghadapi hari raya hari raya umat Islam maupun umat nasrani, sehingga pelanggannya membeli tidak tetap dan dilakukan sendiri pemasarannya belum melibatkan pihak ketiga. Hal ini dapat ditunjukkan pada Gambar 5.
Produk yang dihasilkan 100\% dari keunggulan lokal dan ada pengembangan kreatif yang dilakukan oleh masing-masing pengusaha. Hal inilah yang mendukung program satu desa satu Produk (OVOP) di kawasan terpadu mandiri Rasau Jaya. Sebagian pengusaha sudah mengikuti pelatihan GMP (50\%) namun hanya sebagian besar yang sudah menerapkan GMP sehingga hanya $65 \%$ yang memperhatikan kemasan berlabel dan rata-rata masih menggunakan alat teknologi sederhana. Hanya $2 \%$ yang menggunakan peralatan modern. Menurut Ketua HW Trans Abdul Manan, pengembangan industri rumah tangga juga perlu alih teknologi untuk meningkatkan kualitas. Salah satunya adalah teknologi kemasan selain teknologi pengolahan hasil, untuk kemasan memang harus dibuat semenarik mungkin sehingga bisa memberikan nilai tambah. Standar produksi yang dihasilkan belum mempunyai standar lokal berbasis ekspor atau ber-SNI sehingga 
inilah kendala yang dialami pada program OVOP. Untuk lebih jelasnya dapat dilihat pada Gambar 6.

Kawasan transmigrasi Rasau Jaya ini tidak terlepas dari kegiatan budi daya pertanian yang menghasilkan beragam bahan pangan sehingga industri rumah tangga untuk mengolah bahan pangan itu bisa menjadi pilihan utama dalam meningkatkan nilai tambah dari hasil kegiatan usaha tani yang dilakukan masyarakat dan didukung adanya himpunan wirausaha (HW Trans) yang bisa melaksanakan fasilitasi dalam upaya meningkatkan kapasitas SDM pelaku industri rumah tangga ini. Berikut rekapitulasi kriteria penilaian pengembangan OVOP di kawasan terpadu Mandiri Rasau Jaya.

Tabel 4. Rekapitulasi Kriteria Penilaian Pendekatan OVOP KTM Rasau Jaya

\begin{tabular}{|c|c|c|c|}
\hline ASPEK & DIMENSI & INDIKATOR & SKOR \\
\hline \multirow{15}{*}{ Produksi } & \multirow{3}{*}{$\begin{array}{c}\text { Sumber Bahan Baku } \\
\text { Utama }\end{array}$} & $>$ Bahan baku utama lokal kurang dari $60 \%$ & - \\
\hline & & > Bahan baku utama lokal $60 \%$ - $90 \%$ & $10 \%$ \\
\hline & & > Bahan baku utama lokal lebih dari $90 \%$ & $90 \%$ \\
\hline & \multirow{3}{*}{ Kapasitas Produksi } & $>$ Tidak ada peningkatan kapasitas produksi & - \\
\hline & & >Peningkatan kapasitas produksi kurang dari $30 \%$ & $10 \%$ \\
\hline & & >Peningkatan kapasitas produksi lebih dari 30\% & $90 \%$ \\
\hline & \multirow{3}{*}{ Nilai tambah Produksi } & $>$ Nilai tambah produksi kurang dari $20 \%$ & $5 \%$ \\
\hline & & $>$ Nilai tambah produksi $20 \%-60 \%$ & $20 \%$ \\
\hline & & $>$ Nilai tambah produksi lebih dari $60 \%$ & $75 \%$ \\
\hline & \multirow{3}{*}{ Lingkungan } & >Tidak memperhatikan dampak terhadap lingkungan & $15 \%$ \\
\hline & & $>$ Produksi berdampak terhadap lingkungan tetapi terkendali & $3 \%$ \\
\hline & & >Produksi tidak berdampak terhadap lingkungan & $82 \%$ \\
\hline & \multirow{3}{*}{$\begin{array}{l}\text { Konsistensi kualitas dan } \\
\text { kuantitas produk }\end{array}$} & $>$ Tidak dapat diproduksi dalam kuantitas dan kualitas yang sama & $10 \%$ \\
\hline & & >Dapat diproduksi dalam kuantitas dan kualitas yang hampir sama & $50 \%$ \\
\hline & & > Dapat diproduksi dalam kuantitas dan kualitas yang sama & $40 \%$ \\
\hline \multirow{5}{*}{$\begin{array}{c}\text { Pengembanga } \\
\mathrm{n} \\
\text { Produk }\end{array}$} & \multirow{3}{*}{ Pengembangan Produk } & >Diprodksi sesuai aslinya (tidak ada pengembangan) & $2 \%$ \\
\hline & & > Dikembangkan dari produk asli (diversifikasi) & $68 \%$ \\
\hline & & $>$ Merupakan hasil kreativitas dan inovasi produk & $30 \%$ \\
\hline & \multirow{2}{*}{ Merek } & $>$ Tidak mempunya merek & $40 \%$ \\
\hline & & >Mempunyai merek belum didaftarkan di HKI & $98 \%$ \\
\hline \multirow{6}{*}{$\begin{array}{c}\text { Pengembanga } \\
\mathrm{n} \\
\text { Masyarakat }\end{array}$} & \multirow{3}{*}{ Peran dalam Kelompok } & >Tidak menjadi anggota kelompok & $25 \%$ \\
\hline & & >Sebagai anggota kelompok & $70 \%$ \\
\hline & & $>$ Sebagai Pengurus Kelompok & $5 \%$ \\
\hline & \multirow{3}{*}{ Partisipasi Masyarakat } & >Tenaga kerja sebagian dari masyarakat setempat & $100 \%$ \\
\hline & & >Memberikan sebagian keuntungan kpd masyarakat & $20 \%$ \\
\hline & & $>$ Mendengarkan/menerima masukan dr masyarakat & $40 \%$ \\
\hline \multirow[t]{4}{*}{ Manajemen } & \multirow{3}{*}{ Organisasi } & $>$ Tidak ada struktur organisasi & $98 \%$ \\
\hline & & $>$ Ada struktur oraganisasi tanpa pembagian tugas yang jelas & $2 \%$ \\
\hline & & $>$ Ada struktur organisasi dengan pembagian tugas yang jelas & - \\
\hline & Pembukuan & >Tidak ada pembukuan & $99 \%$ \\
\hline
\end{tabular}




\begin{tabular}{|c|c|c|c|}
\hline ASPEK & DIMENSI & INDIKATOR & SKOR \\
\hline & & >Pembukuan sederhana & $1 \%$ \\
\hline & & >Pembukuan mengikuti sistem akuntansi & - \\
\hline \multirow{18}{*}{$\begin{array}{l}\text { Pemasaran } \\
\text { Riwayat } \\
\text { Poduk }\end{array}$} & \multirow{3}{*}{ Wilayah Pemasaran } & $>$ Wilayah pemasaran utama di provinsi & $100 \%$ \\
\hline & & > Wilayah pemasaran utama antar provinsi & - \\
\hline & & > Wilayah pemasaran utama Internasional & - \\
\hline & $\begin{array}{l}\text { Peningkatan hasil } \\
\text { Penjualan }\end{array}$ & >Kenaikan tidak lebih dari $25 \%$ & $25 \%$ \\
\hline & Produk & $>$ Kenaikan $25 \%-50 \%$ & $60 \%$ \\
\hline & & $>$ Kenaikan $51 \%$ atas lebih & $15 \%$ \\
\hline & Pelanggan & $>$ Mempunyai pelanggan yang membeli tidak tetap & $75 \%$ \\
\hline & & $>$ Mempunyai pelanggan yang membeli secara tetap & $20 \%$ \\
\hline & & $>$ Mempunyai pelanggan yang membeli secara tetap dan meningkat & $5 \%$ \\
\hline & Cara Pemasaran & > Pemasaran dilakukan sendiri & $75 \%$ \\
\hline & & $>$ Pemasaran menggunakan agen/distributor & $25 \%$ \\
\hline & & > Pemasaran menggunakan Online & - \\
\hline & Legenda dari Produk & $>$ Mempunyai riwayat produk tetapi tidak ada dokumentasi & $80 \%$ \\
\hline & & $>$ Mempunyai riwayat produk dan didokumentasi & $20 \%$ \\
\hline & & >Mempunyai riwayat produk ada dokumentasi dan dipubikasikan & - \\
\hline & Kearifan Lokal & >Berasal dari tempat lain dan tidak dikembangkan lebih lanjut & - \\
\hline & & $>$ Berasal dari tempat lain dan dikembangkan lebih lanjut & - \\
\hline & & $\begin{array}{l}\text { >Merupakan asli kearifan lokal dan ada pengembangan kreatif lebih } \\
\text { lanjut }\end{array}$ & $100 \%$ \\
\hline \multirow{15}{*}{$\begin{array}{l}\text { Ketentuan } \\
\text { Umum } \\
\text { Produk }\end{array}$} & Penerapan GMP & $>$ Sudah mengikuti pelatihan GMP tetapi belum diterapkan & $25 \%$ \\
\hline & & $>$ Sudah mengikuti pelatihan GMP dan diterapkan sebagian & $50 \%$ \\
\hline & & >Sudah mengikuti pelatihan GMP dan menerapkan secara penuh & $25 \%$ \\
\hline & Kemasan Label & >Mempunyai kemasan dan label masih sederhana & $30 \%$ \\
\hline & & $\begin{array}{l}\text { >Mempunyai kemasan dan label menarik dan sudah sesuai } \\
\text { ketentuan label }\end{array}$ & $65 \%$ \\
\hline & & $\begin{array}{l}\text { >Mempunyai kemasan dan label menarik sesuai ketentuan label dan } \\
\text { sudah tercamtum info tentang nutrisi }\end{array}$ & $5 \%$ \\
\hline & Peralatan/Teknologi & $>$ Peralatan manual & $75 \%$ \\
\hline & & >Peralatan semi otomatis & $23 \%$ \\
\hline & & $>$ Peralatan Modern & $2 \%$ \\
\hline & Standar Produk & $>$ Tidak mempunyai standar & $89 \%$ \\
\hline & & >Mempunyai stndar perusahaan & $10 \%$ \\
\hline & & $>$ Mempunyai standar perusahaan \& memenuhi SNI & $1 \%$ \\
\hline & & $\begin{array}{l}\text { >Mempunyai stndar perusahaan dan memenuhi Standar } \\
\text { Internasional }\end{array}$ & \\
\hline & $\begin{array}{l}\text { Sertifikasi Sistem } \\
\text { Manajemen }\end{array}$ & $>$ Tidak ada & $99 \%$ \\
\hline & & $>$ Ada & $1 \%$ \\
\hline
\end{tabular}




\section{SIMPULAN}

Kajian ini menyimpulkan bahwa 1) Penerapan model OVOP belum seratus persen berhasil dilakukan karena belum banyak memiliki jaringan yang luas secara nasional atau internasional; 2) Upaya pengembangan produk OVOP sudah dilakukan berupa: Pelatihan, Pendampingan tenaga ahli, Bantuan sarana usaha, Promosi dan Pameran, Fasilitasi HKI. Fasilitasi Permodalan, dan Pemberian penghargaan OVOP; 3) Pengembangan sentra produk One Village One dengan 50 jenis produk sangat mendukung terwujudnya KTM karena mampu menggali potensial daerah Rasau Jaya. 4) Terbentuknya KTM akan menumbuhkan mindset atau perilaku pengusaha transmigrasi Rasau Jaya yang selalu ingin mengembangkan daerahnya melalui penggalian potensi kearifan local dengan mengembangkan Onde Village One Product.

Rekomendasi penelitian ini: 1) Diharapkan pengusaha terus mengembangkan usahanya dengan menggali keunggulan lokal utama sehingga tercipta one village one product (OVOP); 2) Diharapkan dinas perindustrian dan UMKM terus menggiring pengusaha lokal untuk memproduksi produk One Village One Product berbasis ekspor; 3) Hendaknya pemerintah daerah terus berkomitmen terhadap pengembangan produk One Village One Product yang dilakukan oleh masyarakat sehingga terwujudnya Kawasan Industri
Terpadu Mandiri Rasau Jaya yang benarbenar dapat meningkatkan kesejahteraan masyarakat.

\section{DAFTAR PUSTAKA}

Biro Pusat Statistik, 2008, Kondisi Sosial Ekonomi Daerah Perbatasan Kalimantan Barat-Serawak, Biro Pusat Statistik Provinsi Kalimantan Barat, Pontianak.

Borg. W \& Gall, 1989, Educational Research Introduction, New York.

Direktorat Jenderal Insudtri Kecil dan Menengah, 2012, Buku Petunjuk Teknis Penilaian, Klasifikasi dan Pembinaan Produk OVOP, Kementerian Perindustrian Republik Indonesia.

Perempuan Edisi 4 Tahun 2005, ISSN: 1410153x. http://egismy.wordpress.com/ 2009/09/ 08/kawasan-industri-terpaduupaya-peningkatan-daya-saing-produknasional/

Http:www: goegle, 2010, Sekilas Kabupaten Pontianak, Diakses tanggal 12 Maret 2012. I Wayan, 2010, Kawasan Industri Terpadu Mandiri, Harian Kompas, 2010

UU No. 20 Tahun 2008, Undang Undang tentang Usaha Kecil Mikro Menengah, Bandung Penerbit Alfabeta

UU Republik Indonesia Nomor 15 Tahun 1997 tentang Ketransmigrasian, Peraturan

Pemerintah Republik Indonesia Nomor 2 Tahun 1999 tentang Penyelenggaraan Transmigrasi, Jakarta; PT. Rajagrafindo Persada.

Wayan, 2010, Kawasan Industri Terpadu Mandiri, Harian Kompas, 2010 